\title{
Public Services in Election of Regional Chairman
}

\author{
Evy Yuliati*) and Widayati* ${ }^{* *}$ \\ *) Student of Master of Law Program, Faculty of Law Universitas Islam Sultan Agung \\ emaileyuliatimh35@std.unisula.ac.id \\ $\left.{ }^{* *}\right)$ Faculty of Law Universitas Islam Sultan Agung
}

\begin{abstract}
.
The purpose of this article is to describe the form of implementation or public services in regional head elections. This problem is related to several related theories, such as constitutional law theory, democratic law theory, people's sovereignty law theory. This article also discusseslaw and public policies implemented in the elections in Indonesia. MethodThe research used in writing this article is a type of normative legal research. The results of the study indicate that legal theory and public policy are needed in Indonesia. This is done as a basis for implementing democratic practices. The form of implementing laws in constitutional theory is that the KPU establishes KPU Regulations and KPU Decrees in the implementation of Pilkada and provides solutions to problems of implementing law that are contrary to KPU regulations. The mechanism is if there is a PKPU which is deemed contrary to the Election Law, then the examination will be carried out at the Supreme Court in accordance with the provisions in Article 9 paragraph (2) of Act No. 12 of 2011. The implementation of the theory of democratic law in Indonesia is by holding general elections to elect leader, starting from the regional level to the national level. These activities are carried out in order to realize the government system that the people want. The implementation of the theory of popular sovereignty in the Pilkada is the determination of the victory of a candidate for regional head which is determined based on the number of valid votes based on applicable law. The theory of sovereignty also contributes to implementing a democratic system through the principles of people's sovereignty. The conclusion from this research is that the theories that play a role in the implementation of the Pilkada include the theory of democracy, the theory of the constitution, and the theory of people's sovereignty. The three theories are interrelated to support the implementation of Pilkada in accordance with democratic principles. In addition, there are three levels of public policy, namely macro, meso, and micro public policies.
\end{abstract}

Keywords: Implementation of Law; Public Services; Public Policy; Regional Election.

\section{Introduction}

Law is an effort to regulate human life in daily life in relation to the nation and the state. In a society, law functions as a tool to regulate social interaction. ${ }^{1}$ As one of the countries that was once under Dutch colony, Indonesia followed the civil law legal system which was derived from written laws and regulations that were systematically and thoroughly compiled into codification. ${ }^{2}$ Therefore, the main

\footnotetext{
${ }^{1}$ Mawardi, Didiek R. Fungsi Hukum dalam Kehidupan Masyarakat. Jurnal Masalah Hukum, Jilid 44 No. 3, 2015. p. 275.

2 Simbolon, Timbul Mangaratua, Gunarto, dan Umar Ma'ruf. Kebijakan Hukum Pidana Terhadap Tindak Pidana Penghinaan Atau Pencemaran Nama Baik Melalui Internet Di Indonesia sebagai Cybercrime, Jurnal Daulat Hukum, 2018). p. 16.
} 
reference for legal law in Indonesia is a written law. All laws set out in the law contribute to giving everyone moral awareness to apply in accordance with the social context. This provides reciprocity between law and morals in various aspects of human life, namely there is a moral contribution to law and a legal contribution to morality. ${ }^{3}$

As one of the working instruments of the social system, the law must be able to accommodate the needs, interests and provide fair services to the community. The legal development program must be a priority, this is because legal changes to the 1945 Constitution of the Republic of Indonesia have broad and fundamental implications in the constitutional system which need to be followed by changes in the field of law. ${ }^{4}$

The implementation of law in a country should be implemented by the Indonesian people. Rahardjo revealed that "In enforcing the law, there are three elements that must always be considered, namely: legal certainty, benefits, and justice." 5 This was done so that the law could become a priority in developing a country. Indonesia is one of the countries in the world that implements a democratic government system. The implementation of democracy applies the principle that the highest power is in the hands of the people.

Indonesia implements one of the principles of democracy by involving the people directly to elect leaders from the regional level to the national level through elections. Mahfud MD argues that the election of people's representatives is an instrument for realizing people's sovereignty, as a means of articulating the aspirations and interests of the people. ${ }^{6}$ Based on Act No. 10 of 2016 article 7 paragraph 1 states that every citizen has the right to have the same opportunity to run as a candidate for people's representatives in elections. ${ }^{7}$

Elections have a role as a tool of democracy, namely changing the concept of people's sovereignty to become clearer. Elections make for a peaceful change of leadership. ${ }^{8}$ Thus, the election to regions and deputy regional heads (Pilkada) is one form of Indonesia's democratic ideology. In addition, the Pilkada is part of the deepening democracy process and efforts to achieve effective governance. ${ }^{9}$

Pilkada implementation is a manifestation of democratic instruments in order to create a democratic and better government. ${ }^{10}$ This is because this democratic system is a direct mandate that is ordered by the 1945 Constitution,

\footnotetext{
${ }^{3}$ Luthan, Salman. Dialektika Hukum dan Moral dalam Perspektif Filsafat Hukum (Jurnal Hukum IUS QUIA IUSTUM NO. 4, Vol. 19.2012).p. 507.

4 Marzuki, Husni Djalil, dan Mujibussalim. Kedudukan Badan Pembinaan Hukum Nasional dalam Menjalankan Fungsi Legislasi. (Syiah Kuala Law Journal: Vol. 1, No.3, 2017). p. 57.

${ }^{5}$ Dalam Syahri, Alvi. Law Enforcement against Policies Who Breached the Code of Conduct (Jurnal Daulat Hukum. Volume 3 Issue 3, 2020). p.314.

6 Mahfud MD. (2017).Politik Hukum di Indonesia. Jakarta: PT Grafindo Persada. p. 60.

${ }^{7}$ UU no. 10 of 2016 concerning Elections.

8 Budiman, Hendra. Pilkada Tidak Langsung dan Demokrasi Palsu. (Yogyakarta: Pustaka Yustisia, 2015).p. 41.

${ }^{9}$ Solihah, Ratnia. Politik Transaksional dalam Pilkada Serentak dan Implikasinya bagi Pemerintahan Daerah di Indonesia, (Jurnal The Politics: Jurnal Magister Ilmu Politik Universitas Hasanuddin. Vol. 2 No. 1, 2016).p. 98.

10 Hofi, Moh. Ali. Prinsip Kedaulatan Rakyat dalam Mewujudkan Pemilihan Kepala Daerah yang Demokratis (Tesis. Fakultas Hukum Universitas Jember, 2018).
} 
especially Article 1 Paragraph (2) concerning the sovereignty of the people in a democratic country so that the democratic process can be carried out properly. Elections and Pemilukada as a concrete manifestation of democracy in regional governance, should also increasingly reflect the process of democratic maturity. ${ }^{11}$

Pilkada has been going on since 2005 and has had a big impact on society. This makes the Pilkada still a polemic in the community. This is because the Pilkada is considered far from good because there are still many legal cases that occur in the implementation of the Pilkada. ${ }^{12}$

The law enforcement in Pilkada law enforcement is still very low. This was evidenced by the various cases that occurred in the Pilkada. In addition, there are still violations that interfere with the community and there is no guarantee of the safety of community rights. Of course, these various cases have made note of the principles of democracy. In fact, it is important to enforce the law for the interests of the nation and state. ${ }^{13}$ Therefore, there are several characteristics of Pancasila democracy that the founders of the nation want to manifest, especially in the context of supervision, namely: the critical power of the people to the authorities, the people's representatives carry out the mandate with accountability to God, the government's submission to the people. ${ }^{14}$

There are several research and articles related to this article. Articles written by Wardhani (2018) ${ }^{15}$, Alvat (2019) ${ }^{16}$, Darmayanti (2019) ${ }^{17}$, Herlina and Ma'ruf (2019) ${ }^{18}$, Praptini et al. (2019) ${ }^{19}$. These articles discuss how the political process has various problems, such as policies, election fraud, or how the process of implementing rules or policies.

What these studies have in common with this article lies in the study and implementation of laws. Wardani (2018) reveals about the implementation of government regulations, Alvat (2019) examines legal politics, Damayanti (2019) examines the legal politics of legislative elections, Herlina and Ma'ruf (2019) convey law enforcement in elections, and Praptini et al. (2019) examines the

\footnotetext{
11 Nugroho, Wahyu. Politik Hukum Pasca Putusan Mahkamah Konstitusi atas Pelaksanaan Pemilu dan Pemilukada di Indonesia (Jurnal Konstitusi. Vol. 13 No. 3, 2016).

12 Huda, Miftahul. Pola Pelanggaran Pemilukada dan Perluasan Keadilan Substantif (Jurnal Konstitusi, Volume 8, Nomor 2, 2010).

13 Samosir, C. Djisman. Hukum Acara Pidana. (Bandung: Nuansa Aulia, 2018).p. 2.

14 Ridwan, Zulkarnain. Cita Demokrasi Indonesia dalam Politik Hukum Pengawasan Dewan Perwakilan Rakyat terhadap Pemerintah (Jurnal Konstitusi, Volume 12, Nomor 2, 2015).p.311.

15 Wardhani, Pudyastuti Kusuma. Implementation of Government Regulation Number 11 of 2017 in The Making Transparency Candidate Recruitment of Civil Servants in Custody in The Formation of Position Guard Regional Office Ministry of Justice And Human Rights of Central Java (Jurnal Daulat Hukum, Volume 1, Nomor 2, June 2018).

16 Alvat, Andi Pradikta. Politics Of Law Human Rights Protection In Indonesia (Jurnal Daulat Hukum, Volume 2, Nomor 4, December 2019).

17 Darmayanti, Ika Yuana. Law Politics Of Legislative Election (Jurnal Daulat Hukum, Volume 2, Nomor 2, June 2019).

18 Herlina, Sri and Umar Ma'ruf. Law Enforcement Against Elections Crime During Electoral Campaign 2019 (Case Study In Bawaslu of Banjarmasin City) (Jurnal Daulat Hukum, Volume 2, Nomor 3, September 2019).

${ }^{19}$ Praptini, Sri, Sri Kusriyah, Aryani Witasari. Constitution and Constitutionalism of Indonesia (Jurnal Daulat Hukum, Volume 2, Nomor 1, March 2019).
} 
constitution in Indonesia. The difference is related to its varied scope, in this article it focuses on regional elections.

The main purpose discussed in this article is how the form of implementation or public services in regional head elections. These problems are related to several related theories, such as the Theory of Constitutional Law, Theory of Democratic Law, Theory of People's Sovereignty Law.

\section{Research methods}

The research used in writing this article is a type of normative legal research. Normative legal research is research conducted to collect and analyze secondary data. In this normative legal research, only secondary data sources are used. Secondary data used in this study include books, articles of previous research results, laws and regulations, and related legal theories.

\section{Result and Discussion}

In the implementation of constitutional law theory, it also contributes, namely it is used as a basic element of the implementation of democracy in regional elections. In addition, legal theory can be combined with various other elements, such as philosophy of law, sociology of law, to ideal law enforcement. Therefore, in Pilkada, legal theory is needed as a basic implementation of democracy.

There are several legal theories implemented in the Pilkada in Indonesia, namely as follows.

\subsection{Constitutional Law Theory}

In general, state law can mean that power is by norms or the rule of law. ${ }^{20}$ This relates to the highest power contained in the norm or the sovereign, namely the norm or law. Constitutional law is a new science. Therefore, in a broad sense, Constitutional Law (HTN) has three branches of knowledge, namely Constitutional Law, Constitutional Law (HTN) in the narrow sense, and State Administrative Law (HTUN) / Administrative Law. Country (HAN).

The hierarchical system of legal norms or legislation, namely legal theory, considers that a norm must not conflict with the existing norms above it. Hierarchy in this case can be interpreted as a level system of legal rules, or a written legal norm structure in statutory regulations. Therefore, ideally, a regulation formation should not conflict with existing regulations. All rules that are formulated must be in line with the prevailing laws and regulations.

The laws and regulations of the constitutional law regulate the country in terms of its organization. In other words, constitutional law regulations are legal regulations that regulate and determine the state organization of a country. There are two forms of constitutional law regulations, namely constitutional law regulations in the form of written regulations and unwritten regulations.

\footnotetext{
${ }^{20}$ Anwar C. Teori dan Hukum Konstitusi (Paradigma Kedaulatan dalam Undang-Undang Dasar Tahun 1945 Pasca Perubahan, Implikasi dan Implimentasi pada Lembaga Negara, (Malang: Setara Press, 2015).
} 
Regulations that are at the top level underlie the formation of regulations that are under them. The formation of these regulations should pay attention to one of the principles of legislation.

The types and hierarchy of laws and regulations in Indonesia are regulated in the provisions of Article 7 paragraph (1) of Act No. 12 of 2011 as follows: ${ }^{21}$

- The 1945 Constitution of the Republic of Indonesia;

- Decree of the People's Consultative Assembly;

- Laws / Government Regulations in Lieu of Laws;

- Government regulations;

- Presidential decree;

- Provincial Regulation; and

- Regency / City Regional Regulations.

PKPU based on Article 7 paragraph (1) does not exist in the provisions concerning the hierarchy of statutory regulations above. If we only read the provisions in Article 7 paragraph (1) of Act No. 12 Year 2011, we will not find the phrase "KPU regulations" in it. PKPU as part of the hierarchy of laws and regulations will be seen in the substance of the subsequent articles, namely Article 8 paragraph (1) and paragraph (2) of Act No. 12 Year 2011 which reads.

- Types of Laws and Regulations other than those referred to in Article 7 paragraph (1) include regulations stipulated by the People's Consultative Assembly, the House of Representatives, the Regional Representative Council, the Supreme Court, the Constitutional Court, the Supreme Audit Agency, the Judicial Commission, Bank Indonesia, the Minister, agencies, institutions, or commissions that are at the same level as established by law or the government at the behest of the law, the Provincial People's Representative Council, the Governor, the Regency / City Regional People's Representative Council, the Regent / Mayor, the Village Head or equivalent.

- (2) Legislation as referred to in paragraph (1) is recognized for its existence and has binding legal force as long as it is ordered by a higher level of statutory regulations or is established based on authority.

According to the provisions of the Article, PKPU is categorized as a regulation stipulated by a commission at the same level as other state institutions established by law or by the Government by order of a law. Furthermore, PKPU is recognized for its existence and has binding legal force because it is ordered by a higher level of legislation and is formed based on the authority given by law to the KPU.

The implementation of constitutional law theory in the Pilkada is to apply all forms of Pilkada implementation mechanisms listed in the constitutional regulations. The implementer of this constitutional law is PKPU which is the implementation of the laws and regulations as referred to in Article 75 paragraph (1) and paragraph (2) of Act No. 7 of 2017 concerning General Elections which govern the holding of elections.

The form of the application of these laws is that the KPU establishes KPU Regulations and KPU Decrees in the implementation of Pilkada and provides

${ }^{21}$ Article 7 paragraph (1) of Law Number 12 Year 2011 concerning the Establishment of Legislation. 
solutions to problems of implementing laws that are contrary to KPU regulations. The mechanism is if there is a PKPU which is deemed contrary to the Election Law, then the examination will be carried out at the Supreme Court in accordance with the provisions in Article 9 paragraph (2) of Act No. 12 Year 2011.

\subsection{Democratic Legal Theory}

Pilkada is the implementation of democratic principles in Indonesia. This was done to replace the hereditary leadership method as was done by the previous kings in their power. This is as expressed by Benefits who argue that.

"Even that elections simultaneously one of its goals is to strengthen the presidential system of government. It is based on several reasons. One of the fundamental reasons related to the electoral objectives simultaneously to strengthen the presidential system of government that is the experiences that have been passed in Indonesian state for implementing elections. "22

Based on the quotation above, law has an important role in maintaining the cleanliness of democracy in elections. Rousseau (2007) explains that democracy is a process that must be passed by a country to get prosperity. ${ }^{23}$ Democracy will run in accordance with the development of the era which will be influenced by the cultural factors of a country. As a country that implements a democratic government system, Indonesia has high opportunities and advantages in involving the role of society in electing its leaders. Hans Kelsen argues that the idea of democracy comes from freedom. This freedom arises because of the idea of freedom in people's minds. Originally freedom was considered an attitude of freedom from ties or absence from all ties and absence from all obligations. However, this was rejected by Hans Kelsen. He thinks that when humans are in social construction, the idea of freedom cannot be simply assessed and is no longer merely free from bonds. ${ }^{24}$

The emergence of these various legal theories has contributed to the formation of a democratic governance system. The birth of the theory of democratic law provides a real view of the importance of implementing a more orderly and structured democracy. This is to prove that democracy is a continuous process towards perfection. However, the implementation of democracy must be in line with the basis of the state, namely Pancasila and not rigid. Rousseau (2007) argues that if the state places democracy rigidly and ideally, there will never be a real democracy and there will never be democracy. ${ }^{25}$ Therefore, the principle of democracy is in accordance with clear, firm, and just laws.

The implementation of the theory of democratic law in Indonesia is by holding general elections to elect leaders, starting from the regional level to the national level. These activities are carried out in order to realize the government system that the people want. The basic principle of democratic state life shows that

\footnotetext{
22 Manfaat, Moh Priyo. Simultaneously Election Impact On The Presidential System In Indonesia (Jurnal Daulat Hukum. Volume 2 Issue 3, 2019), p. 362.

${ }^{23}$ Rousseau, J. J. Du Contract Social (Perjanjian Sosial), (Jakarta: Visi Media, 2007).

24 Ibid.

25 Ibid.
} 
every citizen has the right to actively participate in the political process ${ }^{26}$ This is in line with the principles of democracy that are implemented by the people, by the people, and for the people. Therefore, elections are an important means of involving the votes of the people directly. One of the implementation of the theory of democratic law is at the Pilkada people's party.

\subsection{The Theory of People's Sovereignty Law}

The theory of people's sovereignty is controversial in the political stage of the history of state power and is a very simple basic idea, that the people must be the highest source of power in a country. ${ }^{27}$ As a country that adheres to a democratic system, all government mechanisms must be implemented in accordance with democratic principles.

The theory of people's sovereignty law has developed since the XV century by reacting to the absolute king's power. This stream was introduced by the Monarchomachen who intended to impose restrictions on the king's power by entering into an agreement. The result of the agreement was the determination of the rights and obligations of both parties as outlined in the Fundamentalist Legislation

The teachings of the monarchomachen were passed on by followers of natural law. According to the teachings of natural law in the XVII and XVIII centuries, individuals have power over themselves which is derived from natural laws. Based on the agreement of society, these individuals form the society and then this society gives up its power to the king. Because natural law is the basis of the king's power, the king's power is limited by natural law. This flow shows that the King gets power from the people, so that the people have the highest power. The people are sovereign, while the king is only the executor of the people's will or decision. One of the figures from the people's sovereignty is JJ Rousseau.

The figure of JJ Rousseau also revealed that people's sovereignty is, in principle, a method or system of solving problems with a certain system that fulfills the general will. The general will is imaginary and abstract in nature, whereas sovereignty is the general will. In addition, JJ Rousseau argued that in a country natural liberty has turned into civil liberty in which the people have their rights. The power of the people as the highest in surpassing the representatives based on the majority of votes from a common will (general will / volente generale).

Based on the history and opinion of the leaders, the theory of people's sovereignty is very much needed by Indonesia as a democracy. The theory of people's sovereignty requires that every action of the government must be based on the will of the people, which in the end all government actions must be accountable to all the people through their representatives. ${ }^{28}$ Meanwhile, democracy is a system of government while the people are the source of driving

\footnotetext{
26 Bisariyadi, dkk. Komparasi Mekanisme Penyelesaian Sengketa Pemilu di Beberapa Negara Penganut Paham Demokrasi Konstitusional, (Jurnal Konstitusi Vol. 9, No. 3, 2012), p. 536.

27 Nurtjahjo, Hendra. Filsafat Demokrasi, (Jakarta: Bumi Aksara, 2006).

28 Tutik, Titik Triwulan. Konstruksi Hukum Tata Negara Indonesia Pascaamandemen UndangUndang Dasar NRI Tahun 1945, (Jakarta: Prenada Media, 2010).
} 
democracy. So the people play a role as the main subject in determining the direction of government.

The implementation of the theory of people's sovereignty in the Pilkada is the determination of the victory of a candidate for regional head which is determined based on the number of valid votes based on the applicable law. The theory of sovereignty also contributes to implementing a democratic system through the principles of people's sovereignty. Fahmi argues that people's sovereignty has four principles, namely: freedom, equality / equality, majority votes, and accountability. ${ }^{29}$ The first two principles are more of the essence of people's sovereignty (called the essential principles) and the second two principles are the procedures for the implementation of people's sovereignty (called the procedural principles). These principles are also used in the preparation of the Pilkada mechanism which has been regulated in the KPU laws and regulations.

Nugroho stated that public policy has a simple level of public policy levels in Indonesia are grouped into three, namely: 1) public policies that are macro or basic in nature, namely the 1945 Constitution, Law, Government Regulations, Presidential Regulations, and Regional Regulations; 2) public policies that are meso in nature or explanatory for implementation in the form of Ministerial Regulations, Ministerial Circular Letters, Governor Regulations, Regent Regulations, and Mayor Regulations. The policy can also be in the form of a Joint Decree or SKB between Ministers, Governors and Regents and Mayors; 3 ) micro public policy is a policy that regulates the implementation or implementation of policies on it. ${ }^{30}$ The form of the policy is a regulation issued by the public apparatus under the Minister, Governor, Regent and Mayor.

Based on this, public policies in the form of laws or regional regulations are public policies that are strategic in nature but have not been implemented. This is because these policies still require the derivation of further policies or explanatory public policies that are often referred to as implementing regulations or guidelines.

Regarding the policy hierarchy in general, Abidin differentiates policies in three levels as follows. ${ }^{31}$

- General policies, namely policies that serve as guidelines or implementation guidelines, whether positive or negative, covering the entire region or agency concerned.

- Implementation policies, namely policies that describe general policies. At the central level, the Government Regulation on the Implementation of Laws.

- Technical policies, namely operational policies that are under implementation policies.

The existence of public policy does not just come just like that, but there is a process for the occurrence of public policy. Starling explained that there are five stages in the process of public policy ${ }^{32}$, namely:

\footnotetext{
${ }^{29}$ Fahmi, Khairul. Prinsip Kedaulatan Rakyat dalam Penentuan Sistem Pemilihan Umum Anggota Legislatif, (Jurnal Konstitusi, Vol.7 No. 3, 2010), p. 130.

30 Nugroho, D, Riant. Kebijakan Publik Untuk Negara-Negara Berkembang, (Jakarta: PT. Elex Media Komputindo, 2006), p. 31.

${ }^{31}$ Abidin, Said Zainal. Kebijakan Publik, (Jakarta: Pancar Siwah, 2004), p. 31-34.

${ }^{32}$ Starling. Managing The Public Sector $8^{\text {th }}$ Edition, (Thompson Wadsworth, Boston, M.A., 2008), p. 13.
} 
- Identification of neds, namely identifying community needs in development by following several criteria, including: analyzing data, samples, statistical data, simulation models, cause and effect analysis and forecasting techniques.

- Formulation of policy proposals that include strategic factors, general alternatives, technology stability and environmental impact analysis,

- Adoption that includes a political feasibility analysis, a combination of several political theories and the use of unemployment techniques.

- Implementation of programs that include organizational forms, scheduling models, translation of decisions, pricing decisions, and implementation scenarios, and

- Evaluation which includes the use of experimental methods, information systems, auditing, and surprise evaluation.

Based on the understanding of the opinions of experts regarding the policy, at least there are points that are important features of the understanding of the policy. Public policy is a government action that has the aim of creating public welfare. In addition, policies are made through systematic stages so that all the main variables of all the problems to be solved are covered. The policy must be implemented by the implementing organization (unit). Policies need to be evaluated so that it is known whether they are successful or not in solving problems. Policies are legal products that must be obeyed and are binding on its citizens.

\section{Closing}

Legal theory and public policy are indispensable in Indonesia. This is done as a basis for implementing democratic practices. Theories that play a role in the implementation of Pilkada include the theory of democracy, the theory of the constitution, and the theory of popular sovereignty. The three theories are interrelated to support the implementation of Pilkada in accordance with democratic principles. In addition, there are three levels of public policy, namely macro, meso, and micro public policies.

Based on this article, it is hoped that the community can actually implement democracy. In addition, the government can also oversee the regional head elections well so that they do not cause problems such as cheating in the General Election, Pilkada or others. For researchers, it is hoped that this article can be used as a theoretical study for future studies.

\section{References}

\section{Journals:}

[1] Alvat, Andi Pradikta. (2019). Politics Of Law Human Rights Protection In Indonesia. Jurnal Daulat Hukum. Volume 2, Nomor 4, December 2019.

[2] Bisariyadi, dkk. (2012). Komparasi Mekanisme Penyelesaian Sengketa Pemilu di Beberapa Negara Penganut Paham Demokrasi Konstitusional. Jurnal Konstitusi. Vol. 9, No. 3.

[3] Darmayanti, Ika Yuana. (2019). Law Politics Of Legislative Election (Jurnal Daulat Hukum. Volume 2, Nomor 2, June 2019. 
[4] Fahmi, Khairul. (2010). Prinsip Kedaulatan Rakyat dalam Penentuan Sistem Pemilihan Umum Anggota Legislatif. Jurnal Konstitusi. Vol.7 No. 3.

[5] Herlina, Sri dan Umar Ma'ruf. (2019). Law Enforcement Against Elections Crime During Electoral Campaign 2019 (Case Study In Bawaslu of Banjarmasin City). Jurnal Daulat Hukum. Volume 2, Nomor 3, September 2019.

[6] Huda, Miftahul. (2010). Pola Pelanggaran Pemilukada dan Perluasan Keadilan Substantif. Jurnal Konstitusi, Volume 8, Nomor 2.

[7] Luthan, Salman. (2012). Dialektika Hukum dan Moral dalam Perspektif Filsafat Hukum. Jurnal Hukum IUS QUIA IUSTUM NO. 4, Vol. 19.

[8] Manfaat, Moh Priyo. (2019). Simultaneously Election Impact On The Presidential System In Indonesia. Jurnal Daulat Hukum. Volume 2 Issue 3, September 2019 ISSN: 2614-560X.

[9] Marzuki, Husni Djalil, dan Mujibussalim. (2017). Kedudukan Badan Pembinaan Hukum Nasional dalam Menjalankan Fungsi Legislasi. Syiah Kuala Law Journal: Vol. 1, No.3 December 2017. ISSN: 2580-9059 (online), ISSN: 2549-1741 (cetak).

[10] Mawardi, Didiek R. (2015). Fungsi Hukum dalam Kehidupan Masyarakat. Jurnal Masalah Hukum, Jilid 44 No.3.

[11] Nugroho, Wahyu. (2016). Politik Hukum Pasca Putusan Mahkamah Konstitusi atas Pelaksanaan Pemilu dan Pemilukada di Indonesia. Jurnal Konstitusi. Vol. 13 No. 3.

[12] Praptini, Sri, Sri Kusriyah, Aryani Witasari. (2019). Constitution and Constitutionalism of Indonesia. Jurnal Daulat Hukum. Volume 2, Nomor 1, March 2019.Ridwan, Zulkarnain. (2015). Cita Demokrasi Indonesia dalam Politik Hukum Pengawasan Dewan Perwakilan Rakyat terhadap Pemerintah. Jurnal Konstitusi, Volume 12, Nomor 2.

[13] Simbolon, Timbul Mangaratua, Gunarto, dan Umar Ma'ruf. (2018). Kebijakan Hukum Pidana Terhadap Tindak Pidana Penghinaan Atau Pencemaran Nama Baik Melalui Internet Di Indonesia Sebagai Cybercrime. Jurnal Daulat Hukum. Vol. 1. No. 1 March 2018 ISSN: 2614-560X.

[14] Solihah, Ratnia. (2016). Politik Transaksional dalam Pilkada Serentak dan Implikasinya bagi Pemerintahan Daerah di Indonesia. Jurnal The POLITICS: Jurnal Magister Ilmu Politik Universitas Hasanuddin. Vol. 2 No. 1, Jan 2016 PISSN: 2407-9138.

[15] Syahri, Alvi. (2020). Law Enforcement against Policies Who Breached the Code of Conduct. Jurnal Daulat Hukum. Volume 3 Issue 3, September 2020 ISSN: 2614-560X.

[16] Wardhani, Pudyastuti Kusuma. (2018). Implementation of Government Regulation Number 11 of 2017 in The Making Transparency Candidate Recruitment of Civil Servants in Custody in The Formation of Position Guard Regional Office Ministry of Justice And Human Rights of Central Java. Jurnal Daulat Hukum. Volume 1, Nomor 2, June 2018.

\section{Books:}

[1] Abidin, Said Zainal. (2004). Kebijakan Publik. Jakarta: Pancar Siwah. 
[2] Anwar C. (2015). Teori dan Hukum Konstitusi (Paradigma Kedaulatan dalam Undang-Undang Dasar Tahun 1945 Pasca Perubahan, Implikasi dan Implimentasi pada Lembaga Negara. Malang: Setara Press.

[3] Budiman, Hendra. (2015). Pilkada Tidak Langsung dan Demokrasi Palsu. Yogyakarta: Pustaka Yustisia.

[4] Mahfud MD. (2017). Politik Hukum di Indonesia. Jakarta: PT Grafindo Persada.

[5] Nugroho, D, Riant. (2006). Kebijakan Publik Untuk Negara-Negara Berkembang. Jakarta: PT. Elex Media Komputindo.

[6] Nurtjahjo, Hendra. (2006). Filsafat Demokrasi. Jakarta: Bumi Aksara.

[7] Rousseau, J. J. (2007). Du Contract Social (Perjanjian Sosial). Jakarta: Visi Media.

[8] Starling. (2008). Managing the Public Sector $8^{\text {th }}$ Edition. Thompson Wadsworth, Boston, M.A.

[9] Samosir, C. Djisman. (2018). Hukum Acara Pidana. Bandung: Nuansa Aulia.

[10] Tahir, Arifin. (2011). Kebijakan Publik dan Transparansi Penyelenggaraan Pemerintahan Daerah. Jakarta: Pustaka Indonesia Press.

[11] Tutik, Titik Triwulan. (2010). Konstruksi Hukum Tata Negara Indonesia Pascaamandemen Undang-Undang Dasar NRI Tahun 1945. Jakarta: Prenada Media.

\section{Thesis:}

[1] Hofi, Moh. Ali. (2018). Prinsip Kedaulatan Rakyat dalam Mewujudkan Pemilihan Kepala Daerah yang Demokratis. Tesis. Fakultas Hukum Universitas Jember.

\section{Regulation:}

[1] Act No. 10 of 2016 concerning Elections 